\title{
Nutritional and environmental studies on an ocean-going oil tanker. 3. Energy balances and physique
}

\author{
T. P.EDDY, ANNE L. STOCK and ERICA F. WHEELER \\ Department of Human Nutrition, London School of Hygiene and Tropical \\ Medicine, Keppel Street, London W.C.1, the Department of Nutrition, \\ Queen Elizabeth College, Campden Hill Road, London W.8, and the Esso Petroleum Company, \\ Esso House, Victoria Street, London S.W.1
}

Eddy, T. P., Stock, Anne L., and Wheeler, Erica F. (1971). Brit. J. industr. Med., 28, 330-341. Nutritional and environmental studies on an ocean-going oil tanker. 3. Energy balances and physique. During the voyage of the oil tanker S.S. Esso Newcastle to the Persian Gulf (July to August, 1967) the average dietary intake of the whole ship's complement was measured on eight days at different periods of the voyage. In addition, the individual intakes of six subjects (three crew and three students) were measured on three occasions over periods of three days. Estimates were also made of the energy expenditures of three members of the crew and body weight and skinfold thickness were measured.

Energy expenditure balanced energy intake in two of the crew members investigated. In the third crew subject, expenditure exceeded intake and there was a slight loss of weight. Two out of the three student subjects showed a significant gain in weight by the end of the voyage.

The average calorie intake for the ship was 15.07 megajoules (MJ) (3600 kcal) per man per day (of which 13.23 MJ (3160 kcal) were derived from non-alcoholic sources). This is the United Kingdom recommended intake for very active men. Issues on the Esso Newcastle were 18.83 MJ (4500 kcal)/man/day; the difference between provision and consumption was found to be similar to that reported for Scandinavian vessels.

Though the crew tended to be heavier than British landsmen, they did not appear to be abnormally fat. Weight was attributable to muscularity.

Dietary requirements are primarily dependent upon energy expenditure and the degree to which this is met by energy intake. Although the closed community of a ship at sea presents an excellent opportunity for dietary measurements, comparatively few assessments of the dietary intake of seamen appear to have been made. Some, based on total storesissues to ships, have given very high estimates of calorie intake. For example, Knap (1950), after allowing $25 \%$ for wastage, concluded that an intake of 30.53 MJ (7294 kcal) per man per day in a Nor- wegian tanker was excessive. In more recent dietary assessments in Norway and Sweden, Øgrim (1962), Grønn and Øgrim (1962), and Isaksson (1969) described energy intakes of between 14.65 and 16.74 MJ (3500 and $4000 \mathrm{kcal}$ ) per man per day.

Because space is limited, activity on board ship is of necessity confined. There have been reports that seamen tend to become overweight and that heaviness increases with the duration of service at sea. The need to measure nutrient intakes and weight changes in the course of climatic and metabolic 
balance studies on the voyage of the tanker S.S. Esso Newcastle provided an opportunity to measure energy intakes and to make estimates of energy expenditures on board ship.

\section{Dietary energy intakes}

\section{Methods}

On eight days at different times extending from the start to the end of the voyage, the weight of all food eaten on board was measured, the weight consumed being obtained for each food or menu-item separately. This was done by weighing all containers and dishes in the galley when they were full of food before each meal, and again after the meal, the weights of each menu-item issued being obtained by subtraction of the final weight from the full weight. All food left uneaten on plates (plate-waste) was scraped into a bucket and weighed. The calculation corrected for plate-waste gave the weights consumed. All bread, sugar, and milk consumed on board during survey days were weighed separately. Snacks taken from refrigerators etc. in pantries were weighed, consumption during the day and night being measured separately. The resulting data were computed using the Human Nutrition Department's programme to show nutrient intake per man per day.

Dietary intakes were also measured in connexion with metabolic balance studies of six subjects. The methods of collection and measurement of food and excretion are described by Collins, Eddy, Hibbs, Stock, and Wheeler (1971).

The metabolizable energy value of the meals which were collected was measured directly by calorimetry using Miller and Payne's bomb calorimeter (Miller and Payne, 1959). The energy value of numerous extrasdrinks, sugar, etc.- - was computed from food tables and, if necessary, subjected to chemical analysis. In addition to direct calorimetric measurements, the computer programme, based on food tables, gave estimates of the energy and protein and other nutrients of all foods taken by each subject. There was a good correlation between the two methods for the net value of meals corrected for waste $(r=0.81$ for each subject's daily intake; $r=0.86$ for the mean intake for each subject over the test periods of three days). The computer results were about 1.05 MJ (250 cal) higher than the assays by calorimeter. The energy values given in this report are derived from the laboratory assays of the sampled meals combined with computed results from food tables for additional snacks and extras (bread, cheese, beer, etc. taken in addition to meals and recorded in diaries). Snacks of this kind are much less variable in composition than are cooked meals and calculations from food tables were adequate for our purpose.

Similarly, Kjeldahl and Soxhlet analyses of the meals for nitrogen and fat were combined with computation of nitrogen and fat contents in snacks and extras to give total protein and fat intakes, and a total computation of all food items including meals was made.

\section{Results}

A comparison of analytical and computed values for meals is given in Table 1 .

A computation from food tables was made from the official records of ship's issues to show the equivalent in nutrients issued per person per day. This was done both for the Esso Newcastle for periods covering this voyage and for a previous voyage by the Esso London. The results are shown in Table 2.

The energy and protein intakes of the six subjects whose diets were measured individually are shown in Table 3.

\section{Discussion}

A comparison of the net consumption of $13.52 \mathrm{MJ}$ $(3230 \mathrm{kcal})$ per man per day with $18.84 \mathrm{MJ}(4500$ kcal) issued in the Esso Newcastle indicates that about one-quarter of the issues were not consumed and presumably wasted.

\section{TABLE 1}

Comparison of Energy and Protein Values of Weighed Intakes of Meals (not including 'Extras') and of Total Intake of Fat (Including Extras) as Estimated by Chemical ANalysis (A) and CalculaTION (C)

\begin{tabular}{|c|c|c|c|c|c|c|c|}
\hline \multicolumn{5}{|c|}{ Intake } & $\begin{array}{l}\text { Correlation } \\
\text { coefficient }\end{array}$ & Regression equation & No. of \\
\hline $\begin{array}{l}\text { Energy } \\
\text { Single day's intake } \\
\text { Average of } 3 \text { days' intake }\end{array}$ & $\begin{array}{l}\cdots \\
\cdots\end{array}$ & $\begin{array}{l}\cdots \\
\cdots\end{array}$ & $\begin{array}{l}\cdots \\
\cdots\end{array}$ & $\begin{array}{l}\cdots \\
\cdots\end{array}$ & $\begin{array}{l}0 \cdot 81 \\
0.86\end{array}$ & $\begin{array}{l}\mathrm{C}=0.98 \mathrm{~A}+1.14 \mathrm{MJ}(282 \mathrm{kcal}) \\
\mathrm{C}=1.00 \mathrm{~A}+0.96 \mathrm{MJ}(230 \mathrm{kcal})\end{array}$ & $\begin{array}{l}54 \\
18\end{array}$ \\
\hline $\begin{array}{l}\text { Protein } \\
\text { Single day's intake } \\
\text { Average of } 3 \text { days' intake }\end{array}$ & $\begin{array}{l}\cdots \\
\cdots\end{array}$ & $\begin{array}{l}\cdots \\
\cdots\end{array}$ & $\begin{array}{l}\cdots \\
\cdots\end{array}$ & $\begin{array}{l}\cdots \\
\cdots\end{array}$ & $\begin{array}{l}0 \cdot 75 \\
0.76\end{array}$ & $\begin{array}{l}C=0.78 A+20 \mathrm{~g} \\
\mathrm{C}=0.79 \mathrm{~A}+20 \mathrm{~g}\end{array}$ & $\begin{array}{l}54 \\
18\end{array}$ \\
\hline $\begin{array}{l}\text { Fat (including extras) } \\
\text { Single day's intake } \\
\text { Average of } 3 \text { days' intake }\end{array}$ & $\cdots$ & $\ddot{\cdots}$ & $\cdots$ & $\begin{array}{l}\cdots \\
\cdots\end{array}$ & $\begin{array}{l}0.49 \\
0.48\end{array}$ & $\begin{array}{l}C=0.51 A+54 \mathrm{~g} \\
\mathrm{C}=0.59 \mathrm{~A}+48 \mathrm{~g}\end{array}$ & $\begin{array}{l}53 \\
17\end{array}$ \\
\hline
\end{tabular}


TABLE 2

Average Nutrient Intakes per Man per Day from Food, excluding Drinks, Corrected for Plate Waste

\begin{tabular}{|c|c|c|c|c|c|c|c|c|c|}
\hline Date & Position & $M J(k c a l)$ & $\begin{array}{c}\text { Protein } \\
(\mathrm{g})\end{array}$ & $\begin{array}{l}\text { Fat } \\
(g)\end{array}$ & $\begin{array}{c}\text { Protein } \\
\text { energy } \%\end{array}$ & $\begin{array}{c}\text { Fat } \\
\text { energy } \%\end{array}$ & $\begin{array}{c}\text { Thiamine } \\
(m g / 1000 \mathrm{kcal}) \\
(4 \cdot 186 \mathrm{MJ})\end{array}$ & $\begin{array}{c}\text { Riboflavin } \\
(\mathrm{mg} / 1000 \mathrm{kcal}) \\
(4 \cdot 186 \mathrm{MJ})\end{array}$ & $\begin{array}{c}\text { Niacin } \\
(\mathrm{mg} / 1000 \mathrm{kcal}) \\
(4 \cdot 186 \mathrm{MJ})\end{array}$ \\
\hline $\begin{array}{cl}\text { July } & 23-24 \\
& 31 \\
\text { Aug. } & 13 \\
15 \\
18 \\
19 \\
20 \\
21\end{array}$ & $\begin{array}{l}\text { English Channel } \\
\text { Cape Verde } \\
\text { L. Marques } \\
\text { Horn of Africa } \\
\text { and } \\
\text { Persian Gulf }\end{array}$ & $\begin{array}{l}10.80(2579) \\
13.00(3106) \\
14.28(3411) \\
14.08(3364) \\
14.76(3527) \\
15.39(3677) \\
12.02(2871) \\
13.83(3304)\end{array}$ & $\begin{array}{r}103 \\
106 \\
108 \\
117 \\
94 \\
120 \\
100 \\
96\end{array}$ & $\begin{array}{l}134 \\
147 \\
166 \\
150 \\
170 \\
185 \\
126 \\
178\end{array}$ & $\begin{array}{l}16 \\
14 \\
13 \\
14 \\
11 \\
13 \\
14 \\
12 \\
12\end{array}$ & $\begin{array}{l}47 \\
43 \\
43 \\
40 \\
43 \\
47 \\
39 \\
48\end{array}$ & $\begin{array}{l}0.56 \\
0.46 \\
0.47 \\
0.53 \\
0.43 \\
0.64 \\
0.67 \\
0.53\end{array}$ & $\begin{array}{l}1 \cdot 32 \\
0 \cdot 60 \\
0 \cdot 61 \\
0 \cdot 50 \\
0.48 \\
0.51 \\
0.56 \\
0.44\end{array}$ & $\begin{array}{l}9 \cdot 4 \\
5 \cdot 8 \\
6 \cdot 8 \\
7 \cdot 0 \\
4 \cdot 9 \\
6 \cdot 7 \\
5 \cdot 4 \\
5 \cdot 8\end{array}$ \\
\hline \multicolumn{2}{|c|}{$\begin{array}{l}\text { Mean } \\
\text { Add energy from alcoholic and } \\
\text { sweet drinks }\end{array}$} & $\begin{array}{r}13.52(3230) \\
2.76 \quad(660)\end{array}$ & 106 & 157 & $13 \cdot 5$ & 45 & 0.54 & 0.60 & $6 \cdot 4$ \\
\hline
\end{tabular}

S.S. Esso Newcastle: Issues on whole voyage

\begin{tabular}{l|l|l|l|l|l|l|l|l|l|l|l|l|l|} 
July $1-31$ & $19.67(4698)$ & 147 & 208 & 13 & 40 & 0.68 & 0.62 & 8.4 & 0.73 & 0.64 & 9.8 \\
\hline Aug. $1-31$ & $18.64(4453)$ & 157 & 176 & 14 & 14 & 0.73 & \\
\hline
\end{tabular}

S.S. Esso London: Issues on whole voyage

\begin{tabular}{|l|l|l|l|l|}
$23.41(5592)$ & 173 & 211 & $12 \cdot 2$ & 34 \\
\hline
\end{tabular}

National Food Survey Consumption 1966

1. All households

2. Households with two adults under 55 years

\begin{tabular}{|l|l|l|}
$10 \cdot 72(2560)$ & $75 \cdot 6$ & 117 \\
$13 \cdot 14(3140)$ & 93 & 150
\end{tabular}

$11 \cdot 8$

41
$43 \cdot 1$

0.63

1

$0 \cdot 58$

$\cdot 58$

In Norwegian ships Grønn and Øgrim (1962) found the same difference of approximately 5.02 MJ $(1200 \mathrm{kcal})$ per man per day between provision and consumption, and Isaksson (1969) reports a similar difference in Swedish ships of about 6.28 MJ (1500 kcal) between consumption measured from dietary recall and provisions issued.

Of the computed mean energy intake of $13.52 \mathrm{MJ}$ $(3230 \mathrm{kcal})$ per head per day exclusive of drinks for the whole ship shown in Table 2, approximately $13.5 \%$ of energy intake was attributable to protein, and $45 \%$ to fat. In addition, approximately $2.76 \mathrm{MJ}$ $(660 \mathrm{kcal})$ per head per day were attributable to soft and hard drinks derived from beer $(70 \%)$, spirits ( $\frac{2}{3}$ rum-15\%), wines, sherry, etc. $(5 \%)$, and soft drinks $(10 \%)$. About $2.5 \mathrm{MJ}(600 \mathrm{kcal})$ were from alcoholic beverages, $2.00 \mathrm{MJ}(470 \mathrm{kcal})$ of which were derived from alcohol. This is roughly equivalent to a daily consumption of 3.7 pints $(6.31$.) of beer. The average consumption of all men and women over 18 years in the United Kingdom is about 0.4 MJ ( 96 alcoholic kcal) per day, equivalent to $3 / 5$ pint $(340 \mathrm{ml})$ of beer. The consumption of alcohol may be slightly over-estimated as it is based on the amount issued from bond and assumes that all issues were consumed within the period of the investigation.

The total mean calorie intake per head per day as computed was therefore $13.52+2.76 \mathrm{MJ}(3230+$ $660 \mathrm{kcal})$, of which approximately 14.27 MJ (3410 kcal) were non-alcoholic. This gives approximately $11 \%$ protein joules and 36 to $37 \%$ fat joules of total energy intake, the proportions of protein and fat energy to total energy found in the National Food Survey and in most British and European diets.

The estimated energy intake of the six subjects computed from food tables exceeded the analytical value by $1.05 \mathrm{MJ}(250 \mathrm{kcal})$. A corrected intake for the whole ship would therefore be approximately 13.23 non-alcoholic and 15.07 total MJ (3160 and $3600 \mathrm{kcal})$. The United Kingdom recommended intake for very active men is $15.1 \mathrm{MJ}$. The average clothed weight of 33 members of the crew was given as $75.5 \mathrm{~kg}$. The FAO recommended allowance for a reference man at this weight would be $14.53 \mathrm{MJ}$ (3470 kcal). Activity for this requirement is rated by 
TABLE 3

Energy and Protein Intakes of 6 SubJects obtained by ANALysis, compared with Minimum RequireMENTS AND RECOMMENDED ALlOWANCES

\begin{tabular}{|c|c|c|c|c|c|c|c|c|}
\hline \multirow[t]{2}{*}{ Subject } & \multirow[t]{2}{*}{ Test } & \multirow{2}{*}{$\underset{(k g)}{\text { Body wt. }}$} & \multirow{2}{*}{$\begin{array}{l}\text { Energy intake } \\
M J(\text { kcal })\end{array}$} & \multicolumn{4}{|c|}{ Protein } & \multirow{2}{*}{$\begin{array}{c}\text { Nitrogen } \\
\text { balance } \\
(\mathrm{g} / \text { day })\end{array}$} \\
\hline & & & & $\begin{array}{l}\text { Minimum } \\
\text { requirement } \\
(\mathrm{g} / \text { day })\end{array}$ & $\begin{array}{c}\text { Intake } \\
\text { (g/day) }\end{array}$ & $\begin{array}{c}\text { Intake } \\
\text { (joules \%) }\end{array}$ & $\begin{array}{c}\text { Intake } \\
(\mathrm{g} / \mathrm{kg} / \text { day })\end{array}$ & \\
\hline A & $\begin{array}{l}1 \\
2 \\
3\end{array}$ & $61 \cdot 7$ & $\begin{array}{l}15.35(3668) \\
12.68(3030) \\
13.07(3122)\end{array}$ & $\begin{array}{l}40 \\
39 \\
42\end{array}$ & $\begin{array}{l}136 \\
127 \\
119\end{array}$ & $\begin{array}{l}15 \\
17 \\
15\end{array}$ & $\begin{array}{l}2 \cdot 2 \\
2 \cdot 1 \\
1 \cdot 9\end{array}$ & $\begin{array}{l}+4.9 \\
+1 \cdot 2 \\
+1.9\end{array}$ \\
\hline B & $\begin{array}{l}1 \\
2 \\
3\end{array}$ & $67 \cdot 7$ & $\begin{array}{l}13.38(3196) \\
10.80(2579) \\
10.88(2598)\end{array}$ & $\begin{array}{l}39 \\
40 \\
42\end{array}$ & $\begin{array}{l}133 \\
108 \\
104\end{array}$ & $\begin{array}{l}17 \\
17 \\
16\end{array}$ & $\begin{array}{l}1 \cdot 7 \\
1 \cdot 4 \\
1 \cdot 3\end{array}$ & $\begin{array}{l}+3.7 \\
+0.1 \\
+1.8\end{array}$ \\
\hline $\mathbf{P}$ & $\begin{array}{l}1 \\
2 \\
3\end{array}$ & $61 \cdot 7$ & $\begin{array}{l}12.67(3026) \\
10.95(2615) \\
12.36(2952)\end{array}$ & $\begin{array}{l}39 \\
39 \\
43\end{array}$ & $\begin{array}{r}108 \\
96 \\
114\end{array}$ & $\begin{array}{l}14 \\
15 \\
15\end{array}$ & $\begin{array}{l}1.8 \\
1.6 \\
1.8\end{array}$ & $\begin{array}{l}+1.4 \\
+1.3 \\
+1.9\end{array}$ \\
\hline D & $\begin{array}{l}1 \\
2 \\
3\end{array}$ & 59.5 & $\begin{array}{r}9 \cdot 64(2304) \\
14 \cdot 17(3384) \\
14 \cdot 15(3381)\end{array}$ & $\begin{array}{l}37 \\
37 \\
39\end{array}$ & $\begin{array}{r}59 \\
110 \\
101\end{array}$ & $\begin{array}{l}10 \\
13 \\
12\end{array}$ & $\begin{array}{l}1 \cdot 0 \\
1 \cdot 8 \\
1 \cdot 7\end{array}$ & $\begin{array}{l}-2 \cdot 7 \\
+2.5 \\
+3.7\end{array}$ \\
\hline$F$ & $\begin{array}{l}1 \\
2 \\
3\end{array}$ & $81 \cdot 1$ & $\begin{array}{l}12 \cdot 12(2896) \\
17 \cdot 53(4187) \\
13 \cdot 55(3237)\end{array}$ & $\begin{array}{l}48 \\
49 \\
50\end{array}$ & $\begin{array}{r}97 \\
131 \\
103\end{array}$ & $\begin{array}{l}13 \\
12 \\
13\end{array}$ & $\begin{array}{l}1.2 \\
1.6 \\
1 \cdot 3\end{array}$ & $\begin{array}{l}+3 \cdot 4 \\
+4 \cdot 8 \\
\pm 0\end{array}$ \\
\hline G & $\begin{array}{l}1 \\
2 \\
3\end{array}$ & $71 \cdot 4$ & $\begin{array}{r}8 \cdot 25(1972) \\
9 \cdot 33(2229) \\
10 \cdot 73(2564)\end{array}$ & $\begin{array}{l}43 \\
43 \\
43\end{array}$ & $\begin{array}{l}59 \\
61 \\
61\end{array}$ & $\begin{array}{l}12 \\
11 \\
10\end{array}$ & $\begin{array}{l}0 \cdot 7 \\
0 \cdot 8 \\
0 \cdot 8\end{array}$ & $\begin{array}{l}-2.7 \\
-0.7 \\
+0.9\end{array}$ \\
\hline \multicolumn{2}{|c|}{$\begin{array}{l}\text { Recommended } \\
\text { allowances U.K. } \\
\text { U.S.A. }\end{array}$} & $\begin{array}{l}65 \\
67-70\end{array}$ & $\begin{array}{l}12.56(3000) \\
11.72(2800)\end{array}$ & & $\begin{array}{l}75 \\
65\end{array}$ & 10 & 0.9 & \\
\hline
\end{tabular}

${ }^{1}$ The minimum requirement is based on a maintenance requirement to replace daily metabolic nitrogen loss:

$10 \mathrm{mgN} /$ basal metabolic joule $(2 \mathrm{mg} /$ basal kcal) $+2.8 \mathrm{mgN} /$ basal J $(0.57 \mathrm{mg} /$ basal kcal) + the measured loss in sweat (Table 3 in Collins et al. (1971)). N weights have been multiplied by $\frac{625}{70}$ to give equivalent weights of dietary protein of NPU 70 .

Basal metabolism was estimated using values given for adults at p. 31 of Durnin and Passmore (1967) from the body weight and the fat per cent of body weight shown in Table 7 .

FAO at $8 \mathrm{hr}$ work, mostly standing, which does not involve more than occasional periods of hard physical labour, with $8 \mathrm{hr}$ non-occupational activity and $8 \mathrm{hr}$ sleep. The FAO definition may be compared with activities recorded in Table 4 . Work (mostly standing) occupied $8 \mathrm{hr}$ when not interfered with by physiological tests for this survey, but sleep lasted little more than $6 \mathrm{hr}$. Values given for Japanese seamen by Koishi (1963) give $8 \mathrm{hr}$ sleep and $8 \frac{1}{2} \mathrm{hr}$ work. The Japanese seamen slept less when the ship passed through hot climates and shift workers slept less than day workers.

Surveys of food consumption in Scandinavian ships have given similar values for energy intake. Detailed accounts of the provision and consumption of food on Norwegian ships are given in two papers by Øgrim (1962) and Grønn and Øgrim (1962). Øgrim calculated that the average intakes were a little less than $16 \cdot 74 \mathrm{MJ}(4000 \mathrm{kcal})$ per day and of this some 2.93 MJ (700 kcal) came from food consumed in the pantry at night. The consumption of fat $(47 \%$ energy attributable to fat) was very high; less milk and cereals and substantially more meat and eggs were used than was customary on shore in Norway. Isaksson's (1969) account of diet in the Swedish Merchant Navy in 1965 gave an average energy intake approximately the same as in the Esso Newcastle of about 14.65 to $15.07 \mathrm{MJ}$ (3500 to 3600 kcal) per man per day. The Swedish seamen had a high intake of nearly $50 \%$ energy from fat (approximately $\mathbf{2 7 5} \mathrm{g}$ per man per day), considerably higher than the $40 \%$ energy from fat in the Swedish national diet. These very high fat intakes appear to be characteristic of Scandinavian ships. A similar high value of $45 \%$ energy from fat was given by the original computation of the Esso Newcastle's diet from food tables (Table 2) but when corrected for energy contributed by beer and an overestimate of 
fat calculated from food tables as compared to analysis (Table 1) the mean value for the whole ship and for the six subjects was 33 to $35 \%$ energy from fat. No mention was made of the consumption of alcoholic drinks in the Scandinavian ships and presumably the ships were 'dry'.

\section{Energy expenditure}

\section{Methods}

Estimates of the energy expenditure of three members of the crew-F, a deck officer cadet, D, a mechanic, and G, also employed in the engine room-and of two medical students (all of whose dietary intakes were measured as described in the previous section) were calculated by applying appropriate calorie values for recorded activities. In the Esso Newcastle all the accommodation, including navigation bridge and engine room, was aft, occupying an area about $130 \times 90 \mathrm{ft}(39.6 \times 27.4 \mathrm{~m})$ at the stern. Vertical distances within the accommodation were $30 \mathrm{ft}$ $(9 \cdot 1 \mathrm{~m})$ from mess rooms on the poopdeck to the operating platform of the engine room and a further $24 \mathrm{ft}$ $(7 \cdot 3 \mathrm{~m})$ below the operating platform and $36 \mathrm{ft}(11 \mathrm{~m})$ above the mess rooms on the poopdeck to the bridge. The accommodation and engine room, therefore, occupied an approximately cubical space of $100 \mathrm{ft}^{3}$ $\left(30 \mathrm{~m}^{3}\right)$ with $9 \mathrm{ft}(2.7 \mathrm{~m})$ space between decks. The accommodation surrounds the engine room. The subjects $D$ and $G$ worked in the engine room and never left this $100 \mathrm{ft}(30 \mathrm{~m})$ cube. The deck cadet $F$ was receiving engine room instruction and also spent most of his time in and around the accommodation aft, though his duties sometimes took him all over the ship from stem to stern.

Estimates of energy expenditure were complicated by these severe restrictions of space. Timed measurements of distances walked in these circumstances would call for a very detailed and complex ergonomic study which would have been unrealistic. The method used was, therefore, to estimate basal or resting energy expenditure from the tables of Durnin and Passmore (1967) (checked for one crew subject $F$ by Douglas bag measurements) and to make appropriate increments for sitting and standing.

Expenditure in movement was estimated by the addition to standing value of values for net energy expenditure of horizontal distance walked, with further additions for vertical movement up or down between decks. Horizontal net energy expenditure per metre walked (i.e., total expenditure per metre less expenditure for standing) was calculated from the value $2.28 \mathrm{~J}(0.544$ gcal) $\mathrm{kg}$ body wt/m given by Brody (1945), which also approximates to average values for subjects recorded by Orsini and Passmore (1951). For vertical movements, net energy expenditures (i.e., expenditure above standing metabolism) were calculated for total loads up to $100 \mathrm{~kg}$ from the data given by Orsini and Passmore for the metabolic cost of walking up and downstairs with various loads. These are $16.74 \mathrm{~J}(4.0 \mathrm{gcal}) \mathrm{kg} /$ vertical m going downstairs and $48.14 \mathrm{~J}$ (11.5 gcal) $\mathrm{kg} /$ vertical m going upstairs. From these values the increments to be added to horizontal movements were calculated. The factors were separately calculated for each subject and applied to each movement. The following is an example:
SUBJECT G: FACTORS

\begin{tabular}{|c|c|c|c|}
\hline $\begin{array}{c}\text { Weight: } 71 \cdot 31 \mathrm{~kg} \\
\text { Resting } \\
\text { Sitting } \\
\text { Standing } \\
\text { Dressing }\end{array}$ & $\begin{array}{l}M J / \min \\
0.005 \\
0.006 \\
0.008 \\
0.013\end{array}$ & & $\begin{array}{l}\text { al/min) } \\
(1 \cdot 2) \\
(1 \cdot 5) \\
(1 \cdot 85) \\
(3 \cdot 0)\end{array}$ \\
\hline & \multicolumn{3}{|c|}{ Net expenditure } \\
\hline Movements & 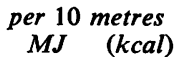 & $\begin{array}{l}\text { per } \\
M J\end{array}$ & $\begin{array}{l}\text { leck } \\
(\text { kcal })\end{array}$ \\
\hline Horizontal & $0.0016 \quad(0.39)$ & & \\
\hline Vertical up & $(8 \cdot 15)$ & 0.010 & $(2 \cdot 3)$ \\
\hline Vertical down & $0.012 \quad(2 \cdot 85)$ & 0.003 & $(0 \cdot 8)$ \\
\hline
\end{tabular}

A typical movement of $\mathrm{G}$ between hospital and cabin:

\begin{tabular}{|c|c|c|c|c|c|}
\hline \multirow[t]{2}{*}{$\begin{array}{l}\text { A } \\
\text { B } \\
\text { C } \\
\text { D }\end{array}$} & $\begin{array}{l}\text { Horizontal } \\
\text { Vertical up } \\
\text { Vertical down } \\
5 \text { min standing }\end{array}$ & $\begin{aligned} 29.6 \mathrm{~m} & = \\
9.14 \mathrm{~m} & = \\
9 \cdot 14 \mathrm{~m} & = \\
& =\end{aligned}$ & $\begin{array}{l}=2.96 \times \\
=3 \text { decks } \\
=3 \text { decks } \\
=5 \times 1.8\end{array}$ & $\begin{array}{l}0.39= \\
\times 2.3= \\
\times 0.8= \\
35=\end{array}$ & $\begin{array}{l}k c a l=M J \\
1.16=0.005 \\
6.9=0.029 \\
2.4=0.010 \\
9.25=0.039\end{array}$ \\
\hline & $\begin{array}{l}\mathbf{A} \\
\mathbf{A}\end{array}$ & $\begin{array}{l}+D= \\
+D=\end{array}$ & $=\begin{array}{c} \\
k c a l \\
17 \\
=12\end{array}$ & $\begin{aligned} & M J \\
= & 0.071 \\
= & 0.050\end{aligned}$ & \\
\hline
\end{tabular}

By allotting suitable standing times for movements from work to cabin, mess, etc., it was possible to disregard the speed of movement.

For specified activities suitable selections were made from Durnin and Passmore's tables. For example, watch duties in the engine room, logging temperature, and pressures, etc. were marked as for a railway signalman, and appropriate values are given for various activities in light engineering.

\section{Results}

The results of these calculations with timed analysis of daily activity are shown in Table 4 and, for comparison, times of sleep, work, and rest in a Japanese tanker.

Table 5 shows the mean energy intakes at each test period of the subjects whose activities were recorded, and compares them with corresponding estimated energy expenditures. Values have been given also as percentages of basal metabolism, which make them roughly comparable.

\section{Discussion}

Apart from work, the only recreational exercise was swimming in a $2 \times 6 \mathrm{~m}$ pool, table tennis, darts or walking on deck. One officer, whose expenditure was not recorded, used a skipping rope.

An investigation of this kind is inevitably complicated by the interference caused to normal routine by the investigation; part of the time that would normally be spent working on watch was spent undergoing tests; this might be exercise in a step test, dressing and undressing for shower baths, or lying at rest for over an hour in a hot bed for 
TABLE 4

Estimated Energy Expenditures: Average of 3 Days

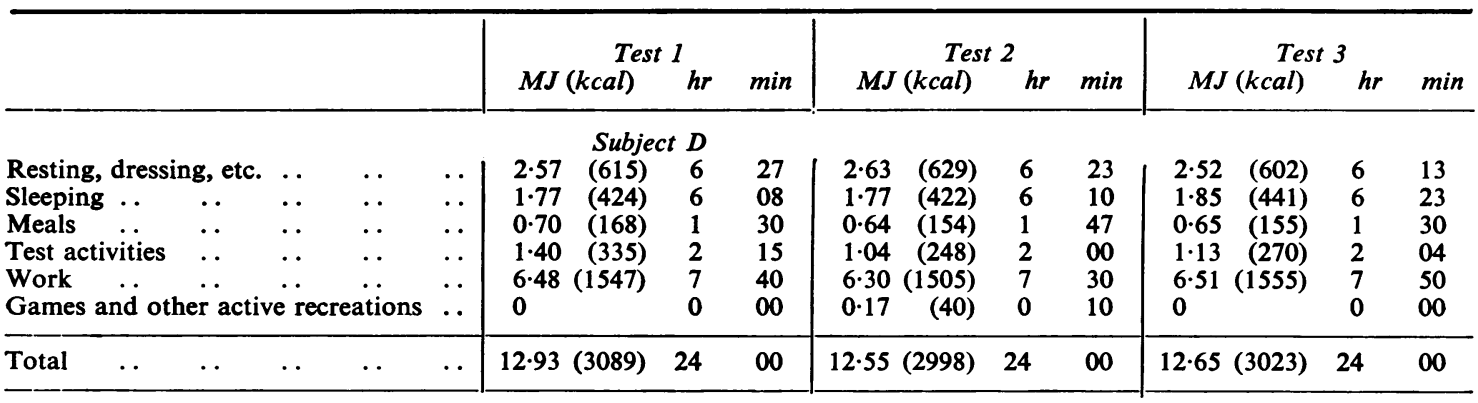

Subject $F$

\begin{tabular}{|c|c|c|c|c|c|c|c|c|c|c|c|c|c|c|c|c|}
\hline & & & & & & & & & & & & & & & & \\
\hline Resting, dressin & g, etc. & . & .. & .. & $3 \cdot 70$ & (884) & 8 & 25 & $2 \cdot 60$ & (621) & 6 & 11 & $2 \cdot 07$ & (494) & 5 & 11 \\
\hline Sleeping .. & .. & .. & . & .. & $2 \cdot 11$ & (505) & 6 & 20 & $2 \cdot 20$ & (525) & 6 & 35 & $2 \cdot 75$ & (658) & 8 & 18 \\
\hline Meals $\ldots$ & . & .. & . & . & 0.47 & (113) & 0 & 58 & 0.43 & (102) & 1 & 00 & 0.45 & (108) & 1 & 03 \\
\hline Movement & .. & .. & .. & .. & 0.67 & (161) & 0 & 67 & 0.62 & (149) & 0 & 47 & 0.53 & (127) & 0 & 48 \\
\hline Test activities & . & .. & .. & $\ldots$ & 0.31 & (75) & 0 & 23 & 1.51 & (360) & 2 & 32 & 1.88 & (449) & 2 & 52 \\
\hline Work .. & .. & $\ldots$ & $\ldots$ & .. & $7 \cdot 48$ & (1787) & 6 & 30 & 5.06 & (1208) & 6 & 15 & $4 \cdot 31$ & (1029) & 4 & 30 \\
\hline Games and othe & er active & e recre & ations & .. & 0.36 & (87) & 0 & 17 & 0.84 & (200) & 0 & 40 & 1.57 & (375) & 1 & 18 \\
\hline Total & $\ldots$ & .. & .. & .. & $15 \cdot 12$ & (3612) & 24 & 00 & $13 \cdot 25$ & $(3165)$ & 24 & 00 & $13 \cdot 56$ & $(3240)$ & 24 & 00 \\
\hline
\end{tabular}

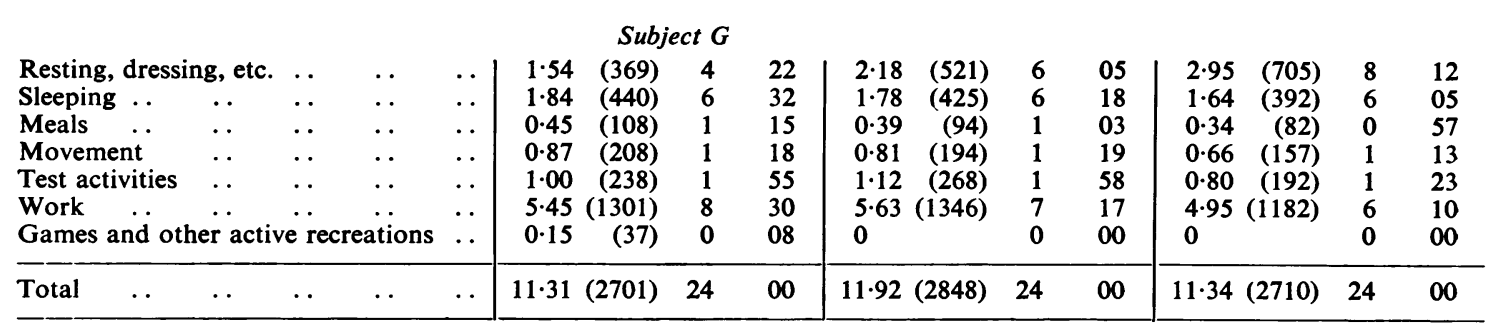

Students' Expenditures Measured on One Day OnLy

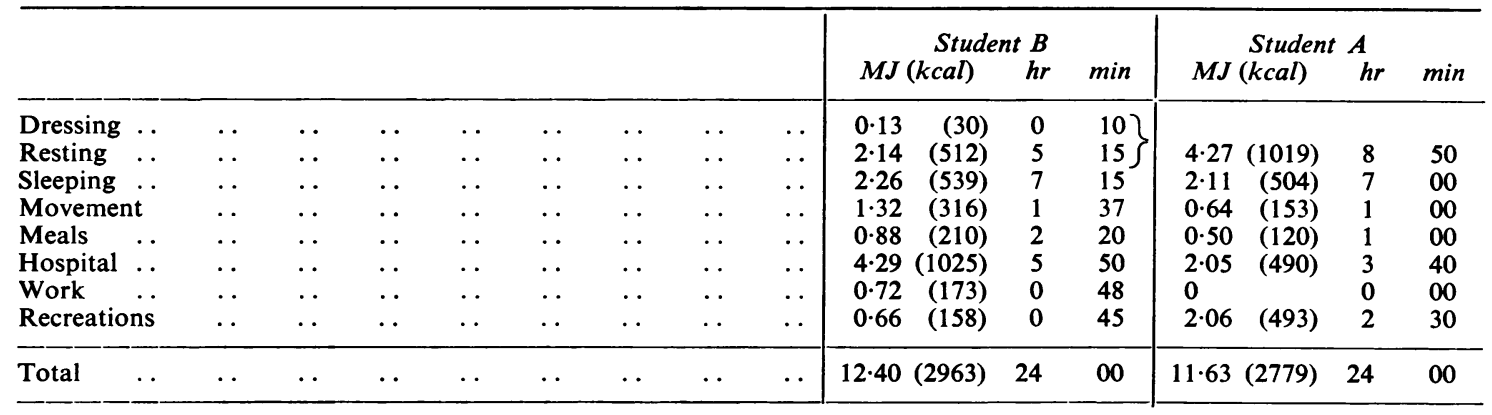

JAPANESE SEAMEN (KoISHI, 1963)

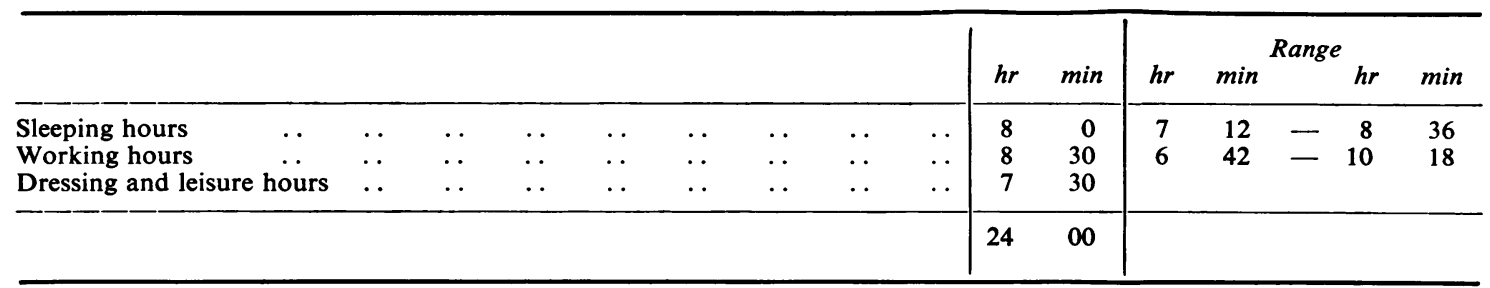


TABLE 5

Mean Daily Energy Intakes and Expenditures of Five Crew Subjects and Two Students

\begin{tabular}{|c|c|c|c|c|}
\hline Test & $\begin{array}{c}\text { Intake } \\
M J(k c a l) / 24 h r\end{array}$ & $\%$ Basal & $\begin{array}{c}\text { Estimated } \\
\text { expenditure } \\
M J(k c a l)\end{array}$ & $\%$ Basal \\
\hline \multicolumn{5}{|c|}{ Subject $D$} \\
\hline $\begin{array}{c}1 \cdot 1 \\
1 \cdot 2 \\
1 \cdot 3 \\
\text { Mean for Test } 1\end{array}$ & $\begin{array}{r}5 \cdot 63(1344) \\
10 \cdot 23(2443) \\
13 \cdot 16(3145) \\
9 \cdot 64(2304)\end{array}$ & 139 & $\begin{array}{l}12.73(3042) \\
13.04(3116) \\
13.02(3110) \\
12.93(3089)\end{array}$ & 186 \\
\hline $\begin{array}{c}2 \cdot 1 \\
2 \cdot 2 \\
2 \cdot 3 \\
\text { Mean for Test } 2\end{array}$ & $\begin{array}{ll}13.08 & (3124) \\
15.47 & (3696) \\
13.95 & (3332) \\
14 \cdot 17 & (3384)\end{array}$ & 203 & $\begin{array}{l}12 \cdot 70(3035) \\
12 \cdot 19(2913) \\
12 \cdot 75(3047) \\
12 \cdot 55(2998)\end{array}$ & 181 \\
\hline $\begin{array}{c}3 \cdot 1 \\
3 \cdot 2 \\
3 \cdot 3 \\
\text { Mean for Test } 3 \\
\text { Mean for all Tests }\end{array}$ & $\begin{array}{l}13 \cdot 71(3276) \\
11 \cdot 60(2771) \\
17 \cdot 12(4091) \\
14 \cdot 15(3381) \\
12.65(3023)\end{array}$ & $\begin{array}{l}202 \\
183\end{array}$ & $\begin{array}{l}12.47(2978) \\
12.42(2966) \\
13.08(3124) \\
12.65(3023) \\
12.65(3023)\end{array}$ & $\begin{array}{l}183 \\
183\end{array}$ \\
\hline
\end{tabular}

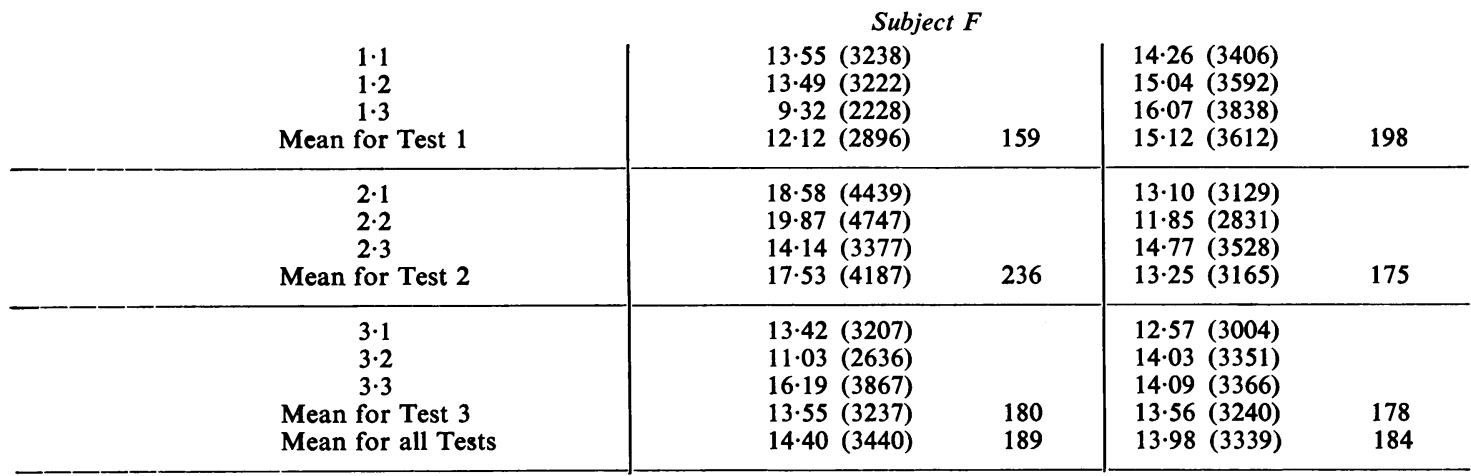

\begin{tabular}{|c|c|c|c|c|}
\hline $\begin{array}{c}1 \cdot 1 \\
1 \cdot 2 \\
1.3 \\
\text { Mean for Test } 1\end{array}$ & $\begin{array}{cc} & S u b j \\
7 \cdot 33 & (1750) \\
9 \cdot 78 & (2337) \\
7.66 & (1829) \\
8.25 & (1972)\end{array}$ & 114 & $\begin{array}{l}10 \cdot 75(2569) \\
10.99(2626) \\
12.18(2910) \\
11.31(2701)\end{array}$ & 152 \\
\hline $\begin{array}{c}2 \cdot 1 \\
2 \cdot 2 \\
2 \cdot 3 \\
\text { Mean for Test } 2\end{array}$ & $\begin{array}{r}7.95(1900) \\
8.93(2133) \\
11 \cdot 12(2656) \\
9.33(2229)\end{array}$ & 129 & $\begin{array}{l}11.04(2637) \\
13.24(3163) \\
11.49(2744) \\
11.92(2848)\end{array}$ & 165 \\
\hline $\begin{array}{c}3 \cdot 1 \\
3 \cdot 2 \\
3 \cdot 3 \\
\text { Mean for Test } 3 \\
\text { Mean for all Tests }\end{array}$ & $\begin{array}{r}8.00(1912) \\
10.81(2583) \\
13 \cdot 38(3197) \\
10 \cdot 73(2564) \\
9.44(2255)\end{array}$ & $\begin{array}{l}148 \\
131\end{array}$ & $\begin{array}{l}11.00(2629) \\
12.41(2964) \\
10.61(2535) \\
11.34(2710) \\
11.52(2753)\end{array}$ & $\begin{array}{l}157 \\
159\end{array}$ \\
\hline
\end{tabular}


Table 5 continued

\begin{tabular}{|c|c|c|c|c|}
\hline Test & $\begin{array}{c}\text { Intake } \\
M J(\text { kcal }) / 24 \mathrm{hr}\end{array}$ & $\%$ Basal & $\begin{array}{c}\text { Estimated } \\
\text { expenditure } \\
M J(\text { kcal })\end{array}$ & $\%$ Basal \\
\hline $\begin{array}{c}1 \cdot 1 \\
1 \cdot 2 \\
1 \cdot 3 \\
\text { Mean for Test } 1\end{array}$ & $\begin{array}{ll} & \text { Stude } \\
15 \cdot 22(3635) \\
17 \cdot 87(4269) \\
12 \cdot 98(3100) \\
15 \cdot 35(3668)\end{array}$ & 213 & $11 \cdot 69$ (2779) & 161 \\
\hline $\begin{array}{c}2 \cdot 1 \\
2 \cdot 2 \\
2 \cdot 3 \\
\text { Mean for Test } 2\end{array}$ & $\begin{array}{l}13.31(3180) \\
12.95(3093) \\
11.80(2818) \\
12.68(3030)\end{array}$ & 175 & & \\
\hline $\begin{array}{c}3 \cdot 1 \\
3 \cdot 2 \\
3 \cdot 3 \\
\text { Mean for Test } 3 \\
\text { Total }\end{array}$ & $\begin{array}{l}11.53(2755) \\
13.75(3285) \\
13.92(3326) \\
13.06(3122) \\
13.70(3273)\end{array}$ & $\begin{array}{l}182 \\
189\end{array}$ & & \\
\hline $\begin{array}{c}1 \cdot 1 \\
1 \cdot 2 \\
1 \cdot 3 \\
\text { Mean for Test } 1\end{array}$ & $\begin{array}{ll} & \text { Stude } \\
13 \cdot 81 & (3300) \\
12 \cdot 72 & (3041) \\
13 \cdot 39 & (3198) \\
13 \cdot 31 & (3180)\end{array}$ & 178 & $12 \cdot 40(2963)$ & 165 \\
\hline $\begin{array}{c}2 \cdot 1 \\
2 \cdot 2 \\
2 \cdot 3 \\
\text { Mean for Test } 2\end{array}$ & $\begin{aligned} 9 \cdot 63 & (2301) \\
10 \cdot 29 & (2460) \\
12.46 & (2977) \\
11.74 & (2805)\end{aligned}$ & 157 & & \\
\hline $\begin{array}{c}3 \cdot 1 \\
3 \cdot 2 \\
3 \cdot 3 \\
\text { Mean for Test } 3 \\
\text { Total }\end{array}$ & $\begin{array}{r}8.72(2082) \\
13.83(3303) \\
10.09(2411) \\
10.88(2599) \\
11.98(2861)\end{array}$ & $\begin{array}{l}145 \\
160\end{array}$ & & \\
\hline
\end{tabular}

acclimatization tests. Other variations in work times and energy expenditures on work are due to adjustments in watch-keeping times; sometimes there were fewer working hours in one period of $24 \mathrm{hr}$ than another. Domestic work, cleaning out cabins, etc. has been counted as work although it was not done during hours on watch. $\mathrm{F}$ also spent considerable time in his cabin studying for a professional examination.

One subject, D, worked a 4-hr watch in the early morning from 0400 to $0800 \mathrm{hr}$ during all three test periods, and a day watch from 1600 to $2000 \mathrm{hr}$. He slept at odd intervals, typical of watch-keeping of this kind; on a typical day he slept for $1 \frac{1}{2} \mathrm{hr}$ at 1230 $\mathrm{hr}$, then had $4 \frac{3}{4} \mathrm{hr}$ sleep in bed before being woken at $0330 \mathrm{hr}$, and slept for $1 \mathrm{hr}$ at $0900 \mathrm{hr}$ the following morning. Much of his own time was spent on his bed reading or on one occasion from 1100 to $1200 \mathrm{hr}$ he 'sat on my bed thinking'. He followed an un- varying routine. His time was spent on watch in the engine room, in his cabin (mostly reading, sometimes talking and drinking with his mates) with about an hour a day spent taking meals in the mess. His estimated daily energy expenditure on nine days had a range of only $0.38 \mathrm{MJ}(91 \mathrm{kcal})$. G also spent his time between cabin, mess, and engine room with a range of $12.55 \mathrm{MJ}(147 \mathrm{kcal})$. Movements from place to place (other than movements demanded by duties on watch) occurred less than a dozen times each day, between watches and between meals.

$F$, the officer cadet, had to learn every aspect of ship's managements and his activities were more varied. The range was $1.87 \mathrm{MJ}(447 \mathrm{kcal})$ between $13 \cdot 25 \mathrm{MJ}(3165 \mathrm{kcal})$ per day minimum and $15 \cdot 12$ MJ (3612 kcal) per day maximum in his daily expenditure. He had a wide variety of working duties, from studying in his cabin to moving timber about the deck (which he described as heavy work), inspect- 
ing and operating fire-fighting equipment, and inspecting temperature-recording equipment for this investigation. This last activity took him to 34 instrument stations on the ship, from the bridge deck to the pumproom plates, and from the galley aft to the bosun's store above the forepeak, requiring some $450 \mathrm{~m}$ horizontal movement and $36 \mathrm{~m}$ vertical movement up and down. Of the three crew subjects whose activities were recorded, $\mathrm{F}$ was the only one who engaged in any recreational activity. He played table tennis with vigour and also darts. A game of table tennis lasts for about 10 to 15 minutes and this cannot make any great contribution to the total day's energy expenditure. The longest period recorded for playing games was $100 \mathrm{~min}$ on two occasions when estimated expenditures were 1.88 and $2.20 \mathrm{MJ}$ (450 and $525 \mathrm{kcal}$ ). On other occasions about $30 \mathrm{~min}$ was spent in play with an expenditure of about $0.63 \mathrm{MJ}(150 \mathrm{kcal})$. Even at their most vigorous, these games accounted for only a small proportion of total expenditure because the time spent in playing them was relatively short, occupying only a small part of the whole day's activities.

D's routine work in the engine room on the control platform was mostly inspection, logging temperatures and pressures, and maintenance of equipment. During the voyage, however, repairs were made to both boilers. The engine room work and the conditions in which it was done are described by Collins, Eddy, Lee, and Swann (1971). Much of this work was very arduous, but the high ambient temperatures meant that, even on jobs taking some hours to complete, work was interrupted by periods of rest and, if not so interrupted, the men would have become inefficient through exhaustion. For example, cleaning and regreasing the air conditioning plant on 9 August by $\mathrm{G}$ over $2 \mathrm{hr}$ was done in periods of 5 to $10 \mathrm{~min}$ work and 5 to $10 \mathrm{~min}$ rest. $D$ and $G$ did most of their work above and around the boilers and on the engine room platform. It is clear from the paper on thermal environment by Collins and his colleagues (1971) that only limited amounts of physical work can be done in these conditions. D occasionally entered in his diary of engine room activities that he 'had a good blow', that is, he stood in the forced draught of the ventilators. Although the energy requirement for this work appears to have been small, heat-stress may have affected protein nutrition and nitrogen balance.

\section{Anthropometry and physique}

Their reputed heights and weights were given by 33 members of the crew. Comparison with the weightfor-height standard, based on the British anthropometric data of Kemsley, Billewicz, and Thomson (1962), after a $10 \mathrm{lb}(4.5 \mathrm{~kg})$ correction for clothed weight and correction for age, gave 10 with 'normal' weights (within the distribution of the upper and lower quartiles about the mean), 7 lightweights (below the lower quartile), and 16 heavyweights (above the upper quartile). It would be expected that half the total of a representative group of British men would be in the 'normal' group but there was a tendency among the seamen to be heavy; less than half the subjects had 'normal' weights. The mean age of the heavy group was about five years older than the other two groups, but the difference was not statistically significant.

Skinfold measurements of the three students and a total of five crew subjects were made with Harpenden calipers. Tables 6 and 7 show skinfold measurements and the height, weight, and physical characteristics of all eight subjects.

\section{Discussion}

The general distribution, with a high proportion of heavyweights among 33 members of the crew, might suggest that energy intake may exceed requirements, but a definition of 'obesity' based on weight for height tables, without any direct measure of fatness, may be deceptive. Tables 6 and 7 show that the 'heavy' subjects were not abnormally obese and had normal or high muscle-scores.

Figure 1 shows that the weight changes of crew members during the balance studies generally showed some correspondence with estimated energy balances and nitrogen balances. The weight changes of the students generally corresponded with calorie intake.

The crew subjects did not change weight greatly over the period of the study.

$\mathrm{D}$, who was 12 to $17 \mathrm{~kg}$ below average weight, gained $1 \mathrm{~kg}$ in weight during the voyage. He said (and this was confirmed by other members of the crew) that he did not usually eat much at the beginning of a voyage but made up for it later. Table 5 shows that in the first test his expenditure exceeded his intake, but this was made good by positive balances in the last tests.

$G$ was a man of average weight; he had a fairly consistent loss of weight totalling $0.71 \mathrm{~kg}$ over the whole period of the tests ( 26 days). His intake, which was the lowest of all the subjects, appears to have been less than his energy expenditure and his muscle score showed a slight fall.

F was 'heavy'. His weight changed very little.

The students $\mathbf{P}$ and $\mathbf{A}$ were both tall and thin, 10 to $15 \mathrm{~kg}$ below average weight and below the limits for desirable weight. A's weight increased by $2.3 \mathrm{~kg}$ (total intake $189 \%$ estimated basal metabolism), and P's by $1 \mathrm{~kg}$ (intake $171 \%$ basal). Student B was $1 \mathrm{~kg}$ above average weight and his weight increased by less than $0.5 \mathrm{~kg}$ (intake $160 \%$ basal). The weight changes generally appeared to correspond with calorie intake. 
TABLE 6

SKINFOLD MEASUREMENTS

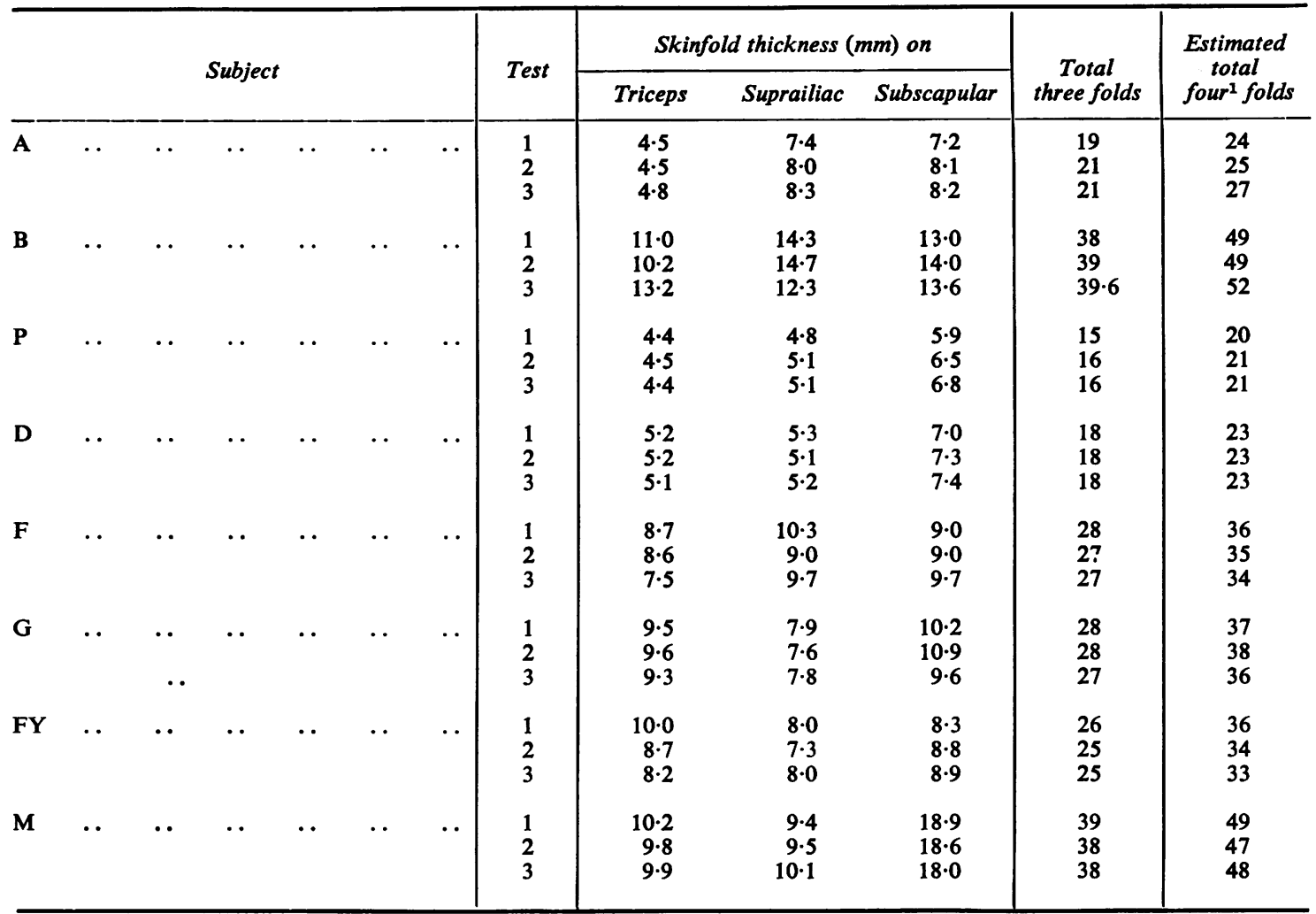

${ }^{1}$ The total'of four skinfold measurements is obtained by doubling the triceps skinfold in place of biceps and triceps.

TABLE 7

Physical Characteristics of Subjects

\begin{tabular}{|c|c|c|c|c|c|c|c|c|c|c|c|c|c|c|c|c|}
\hline Subject & Occupation & $\begin{array}{l}\text { Age } \\
(y r)\end{array}$ & $\begin{array}{c}\text { Height } \\
(\mathrm{cm})\end{array}$ & $\begin{array}{c}\text { Weight } \\
(\mathrm{kg})\end{array}$ & $\begin{array}{c}\text { Surface } \\
\text { area } \\
\left(m^{2}\right)\end{array}$ & $\begin{array}{c}\text { Test } \\
1\end{array}$ & $\begin{array}{c}\text { Test } \\
2\end{array}$ & $\begin{array}{c}\text { Test } \\
3\end{array}$ & $\begin{array}{c}\text { Test } \\
1\end{array}$ & $\begin{array}{c}\text { Test } \\
2\end{array}$ & $\begin{array}{c}\text { Test } \\
3\end{array}$ & $\begin{array}{c}\text { Test } \\
1\end{array}$ & $\begin{array}{c}\text { Test } \\
2\end{array}$ & $\begin{array}{c}\text { Test } \\
3\end{array}$ & $\begin{array}{l}\text { Height } \\
\text { score }\end{array}$ & $\begin{array}{c}\text { Weight related } \\
\text { to height }\end{array}$ \\
\hline $\begin{array}{c}\text { A } \\
\text { B } \\
\mathbf{P} \\
\mathbf{D} \\
\mathbf{F} \\
\mathbf{G} \\
\mathbf{F Y} \\
\mathbf{M}\end{array}$ & $\begin{array}{l}\text { Student } \\
\text { Student } \\
\text { Student } \\
\text { Mechanic } \\
\text { D/Cadet } \\
\text { FWT } \\
\text { E/Cadet } \\
\text { FWT }\end{array}$ & $\begin{array}{l}19 \\
19 \\
19 \\
21 \\
20 \\
30 \\
19 \\
45\end{array}$ & $\begin{array}{l}183 \\
174 \\
183 \\
178 \\
190 \\
173 \\
179 \\
160\end{array}$ & $\begin{array}{l}61 \cdot 65 \\
77 \cdot 68 \\
61 \cdot 69 \\
59 \cdot 52 \\
81 \cdot 10 \\
71 \cdot 37 \\
74 \cdot 74 \\
82 \cdot 71\end{array}$ & $\begin{array}{l}1.81 \\
1.92 \\
1.81 \\
1.74 \\
2.10 \\
1.84 \\
1.93 \\
1.85\end{array}$ & $\begin{array}{l}10 \\
19 \cdot 5 \\
9 \\
10 \cdot 5 \\
16 \\
16 \\
16 \\
19 \cdot 5\end{array}$ & $\begin{array}{c}11 \cdot 5 \\
19 \cdot 5 \\
9 \\
10 \cdot 5 \\
15 \cdot 5 \\
16 \\
15 \\
19\end{array}$ & $\begin{array}{c}12 \cdot 5 \\
20 \cdot 5 \\
9 \cdot 5 \\
10 \cdot 5 \\
15 \cdot 0 \\
16 \\
15 \\
19\end{array}$ & $\begin{array}{l}-1 \frac{1}{4} \\
+\frac{1}{2} \\
-1 \frac{3}{2} \\
-\frac{1}{2} \\
\mathrm{~N} \\
-\frac{3}{4} \\
-\frac{3}{2} \\
-\frac{1}{2}\end{array}$ & $\begin{array}{l}< \\
= \\
= \\
= \\
> \\
= \\
> \\
=\end{array}$ & $\begin{array}{l}< \\
= \\
= \\
= \\
= \\
= \\
= \\
=\end{array}$ & $\begin{array}{l}-\frac{3}{4} \\
+\frac{1}{2} \\
+\frac{1}{4} \\
+\frac{3}{4} \\
-\frac{1}{2} \\
+\frac{1}{2} \\
+\frac{3}{4} \\
+2 \frac{1}{2}\end{array}$ & $\begin{array}{l}= \\
= \\
= \\
= \\
< \\
> \\
= \\
=\end{array}$ & $\begin{array}{l}\gg \\
= \\
\gg \\
= \\
> \\
= \\
= \\
=\end{array}$ & $\begin{array}{l}+2 \frac{1}{2} \\
+1 \frac{1}{2} \\
+2 \frac{1}{2} \\
+1 \frac{1}{2} \\
+4 \\
+1 \\
+1 \frac{1}{2} \\
-2\end{array}$ & $\begin{array}{l}\text { Light } \\
\text { Heavy } \\
\text { Light } \\
\text { Light } \\
\text { Heavy } \\
\text { Normal } \\
\text { Heavy } \\
\text { Heavy }\end{array}$ \\
\hline
\end{tabular}

${ }^{1}$ Fat \% body weight is calculated from the table of Durnin and Rahaman (1967): biceps skinfold was not measured and the triceps skinfold was doubled to give an approximate measure of triceps and biceps. This probably exaggerates body fat content of the fatter subjects.

${ }^{2}$ Fat scores are based on Parnell's 7-point scale for Harpenden calipers (Parnell, 1958). The scores make allowance for increasing fat with age.

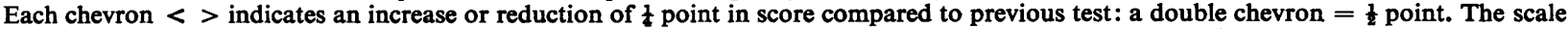
has been shifted: Parnell's $4=\mathrm{N}$ on this chart and scores range + or - around $\mathrm{N}$, the 'normal' degree of fatness.

${ }^{3}$ Muscle scores are based on Parnell's 'Height corrected lean volumes' (Parnell, 1965) with a similar shift of score equating Parnell's 4 to N.

"Height scores show $5 \mathrm{~cm}(2 \mathrm{in})$ points above or below $170 \mathrm{~cm}(67 \mathrm{in})$.

'Classification of weight related to height is based on the weight for height standards of Kemsley et al. (1962). 'Heavy' and 'light' are above or below upper or lower quantiles. 


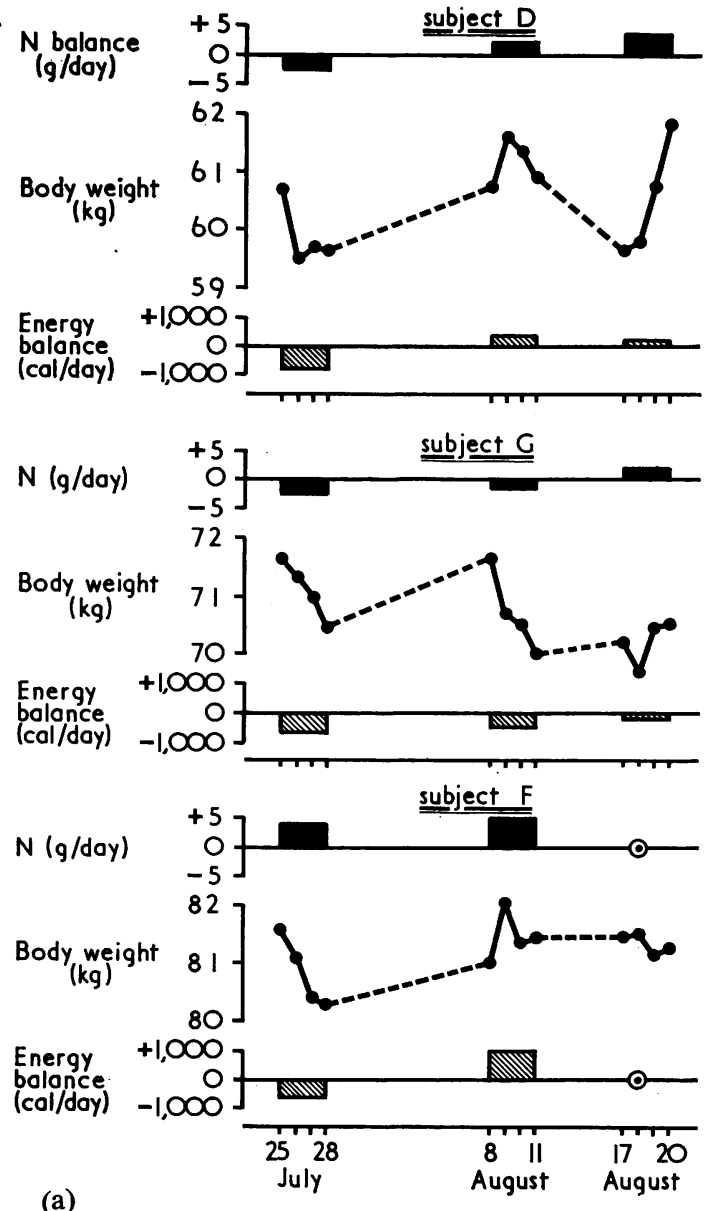

The changes in physical characteristics in the course of the voyage, shown in Table 7 , reveal interesting differences between the crew, who were living their normal working life, and the students who were similar to passengers on a cruise. Though the students did some work, it was relatively light and was not full-time. None of the crew investigated made consistent gains in weight, none of them became fatter; indeed, there was a tendency for them to lose fat and they maintained muscularity as shown by the muscle-score.

The two light and lean students, $P$ and $A$, both increased in weight, particularly A. A's increase was due to increasing fat, and the muscle-score of both these students declined. Although by chance they had identical weights and heights at the start of the voyage, the additional parameter of skinfolds clearly distinguished them physically. This statistical distinction corresponds with the visual impression that $\mathbf{P}$ was extremely lean, more so than $\mathbf{A}$.
$N(g /$ doy $)$

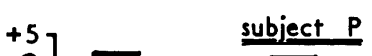

Body weight

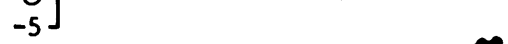

$N(g /$ doy $)$

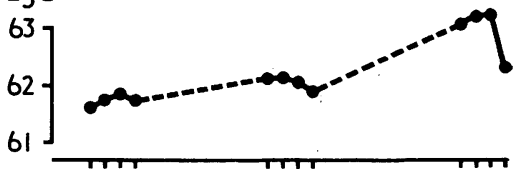

+5 subject $B$

$N(g /$ day $)$

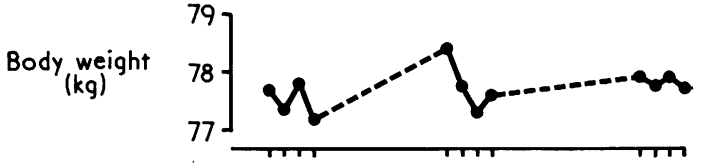

Body weight

$(\mathrm{kg})$

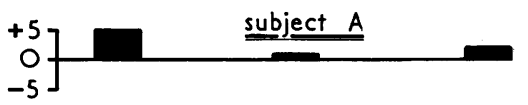

FIG. 1. (a) Nitrogen balances, weight changes, and energy balances of three crew subjects.

(b) Nitrogen balances and weight changes of three student subjects.

In a comparative study of Norwegian seamen and landsmen, Natvig and Vellar (1965) showed that seamen matched landsmen in height but (except at ages 20 to 30) were heavier than landsmen. The difference tended to increase progressively after the age of 30 years, and over this age officers tended to be heavier than men. The discrepancy increased with the length of service at sea. Though Esso tanker officers and crew appear to have been heavier than British landsmen, and are overweight by British standards, the five subjects investigated (three of whom were young men) did not appear to be obese in comparison with normal British men. Clearly, a simple comparison of weight and height is not, in these circumstances, an adequate measure of relative obesity or overnutrition. Skinfold measurements, provided they are done carefully and accurately at routine medical examinations, are a clinical measurement, which can give very useful information on health and nutritional state. 


\section{Nutritional value of food}

Changes in nutrient intakes in the progress of the voyage, inter-relationships of the energy-yielding constituents of the diet, particularly the relationship of alcohol to other constituents, and vitamin intakes will be dealt with in another paper dealing specifically with food and nutrition.

\section{References}

Brody, S. (1945). Bioenergetics and Growth, p. 912. Reinhold, New York.

Collins, K. J., Eddy, T. P., Hibbs, A., Stock, A. L., and Wheeler, E. F. (1971). Nutritional and environmental studies on an ocean-going oil tanker. 2. Heat acclimatization and nutrient balances. Brit. J. industr. Med., 28, 246258. and environmental studies on an ocean-going oil tanker. 1. Thermal environment. Brit. J. industr. Med., 28, 237 245.

Durnin, J. V. G. A., and Passmore, R. (1967). Energy, Work and Leisure. Heinemann, London.

- and Rahaman, M. M. (1967). The assessment of the amount of fat in the human body from measurement of skinfold thickness. Brit. J. Nutr., 21, 681-689.

Grønn, M., and Øgrim, M. M. (1962). Proviantforbruk i Landelsskip (Consumption of food in merchant ships). Forsknings resultaten fra Landsforeningen for Kosthold og Helse, Meld. No. 3, pp. 32, Hyg. Inst. Univ. Oslo.

Isaksson, B. (1969). Personal communication of paper published in J. Swedish Merchant Navy Stewards.

Kemsley, W. F. F., Billewicz, W. Z., and Thomson, A. M. (1962). A new weight-for-height standard based on British anthropometric data. Brit. J. prev. soc. Med., 16, 189-195.
Knap, J. (1950). The caloric value of the fare at sea in the Norwegian Merchant Marine. J. roy. nav. med. Serv., 36, 72-78.

Koishi, Y. (1963). Studies on food supply to seafarers on board vessels: appetite and leavings at the table. J. Sci. Lab. (Tokyo), 39, 279-297.

Miller, D. S., and Payne, P. R. (1959). A ballistic bomb calorimeter. Brit. J. Nutr., 13, 501-508.

Ministry of Agriculture, Fisheries and Food (1968). Household Food Consumption and Expenditure: 1966. Annual Report of the National Food Survey Committee. H.M.S.O., London.

Natvig, H., and Vellar, O. D. (1965). Høyde-og vektundersøkelser av norske sjømenn og menn i land. (Height and weight studies of Norwegian seamen and men ashore.) Forsknings resultaten fra Landsforeningen for Kosthold og Helse, Meld No. 8, pp. 24, Hyg. Inst. Univ. Oslo.

Øgrim, M. E. (1962). Kostholds undersøkelser Landelsskip. (Dietary surveys in merchant ships.) Forsknings resultaten fra Landsforeningen for Kosthold og Helse, Oslo. Meld No. 1, pp. 24, Hyg. Inst. Univ. Oslo.

Orsini, D., and Passmore, R. (1951). The energy expended carrying loads up and down stairs: experiments using the Kofranyi-Michaelis calorimeter. J. Physiol. (Lond.), 115, 95-100.

Parnell, R. W. (1958). Behaviour and Physique; an Introduction to Practical and Applied Somatometry. Arnold, London.

(1965). Human size, shape, and composition. In Human Body Composition: Approaches and Applications, edited by J. Brožek, pp. 61-72. Pergamon, Oxford.

Received for publication August 11, 1970. 